\title{
BAHASA KIASAN DALAM CERPEN "SURABAYA" KARYA TOTILAWATI TJITRAWASITA
}

\section{FIGURATIVE LANGUAGE OF SHORT STORY "SURABAYA" BY TOTILAWATI TJITRAWASITA}

\author{
Yulitin Sungkowati \\ Balai Bahasa Jawa Timur, Jalan Siwalanpanji, Buduran, Sidoarjo, Indonesia 61252, Telepon/ \\ Faksimile (031) 8051752, Pos-el: yulitins@yahoo.com
}

\begin{abstract}
A bstract
This rearchis aimed todkscribethefigurativelanguage of shot story "Surabaya" of Tdilavati Tjitranasita. The prodems of rearch fousarewhat arethefigurativelanguagein short stayandhowareits effets? Therearchused qualitativemethod by usingread and notel techniques Therearch has results that figurativelangrage of theshot storyarepesonification, simile andmothaporeAll of themdominated narration of theshort staryand theygt effect of imaginativecration of a suffeingvillageand vident dity.
\end{abstract}

Keyw ords: stary, figurative, effet

\begin{abstract}
Abstrak
Penelitian ini bertujuan mengungkap bahasa kiasan yang ada dalam cerpen "Surabaya" karya Totilawati Tjitrawasita. Masalah yang menjadi fokus penelitian, yakni bahasa kiasan apa sajakah yang ada dalam cerpen "Surabaya" karya Totilawati Tjitrawasita dan bagaimanakah efeknya. Metode yang digunakan adalah metode kualitatif dengan teknik baca dan catat. Penelitian ini menghasilkan temuan bahwa bahasa kiasan yang banyak digunakan dalam cerpen "Surabaya" adalah personifikasi, simile, dan metafora. Ketiga bahasa kiasan itu mendominasi narasi cerpen dan menimbulkan efek terciptanya gambaran angan tentang sebuah dusun yang merana dan sebuah kota yang kejam.
\end{abstract}

Kata kunci: cerpen, kiasan, efek

\section{PENDAH ULUAN}

Totilawati Tjitrawasita adalah salah satu pengarang perempuan dari Jawa Timur yang kepengarangannya di Surabaya dikelompokkan dalam periode 1970-1980 oleh Suripan Sadi Hutomo (1995) dalam buku Wajah Sastra Indonesia di Surabaya Hutomo (1995) mengatakan bahwa di antara pengarang perempuan yang aktif berkarya pada periode tersebut, yaitu Sri Amiranti Sastrohoetomo, Titik D anumihardja, Siti Rohani, D enok Rachmawati, Soraya, D wiarti Mardjono, Regina Bimadona, Lila Ratih Komala, Peggy Laoh, dan Ida Rosyad, nama Totilawati Tjitrawasita paling menonjol. Hal itu tidak hanya dikarenakan oleh nafas kepengarangannya yang cukup panjang, tetapi juga karena karya-karyanya dinilai berkualitas. Pengarang kelahiran Kediri pada tanggal 1 Juni 1945 ini lahir dari keluarga jurnalis dan menempuh pendidikan jurnalisnya di Akademi Wartawan Surabaya. Selanjutnya, ia bekerja sebagai wartawan di majalah berbahasa Jawa/ Indonesia Jayabaya di Surabaya.

Totilawati Tjitrawasita dikenal sebagai pengarang dwibahasa: bahasa Jawa dan bahasa Indonesia. Cerpennya masuk dalam berbagai antologi dan bukunya yang telah terbit adalah Sebuah Cinta Sakdah Rakyat, Hadiah Ulang Tahun Sinta Susanti, dan Bonka Mimi. Pengakuan atas kualitas karya- 
nya dapat ditelusuri dari tulisan HB. Jassin dalam buku LangtBinuLautBinuyang membahas cerpen "Jakarta". Cerpen "Jakarta" masuk dan menjadi judul kumpulan cerpen terbitan Dewan Bahasa dan Pustaka Malaysia serta masuk dalam buku Ceita Pendk Indonesia (1987) yang disunting oleh Satyagraha Hoerip. Cerpen "Jakarta" menjadi contoh analisis cerita rekaan yang dilakukan Panuti Sudjiman dalam buku Memahami Ceita Rekaan (1991) dan menjadi buku pedoman mahasiswa untuk menganalisis karya sastra.

Pena dan bahasa merupakan senjata andalan seorang wartawan. Karya-karya Totilawati Tjitrawasita tidak hanya dikenal menghadirkan tokohtokoh perempuan yang tegar dan tabah menghadapi perubahan zaman (Sungkowati, 2013: 63), tetapi juga dinilai piawai dalam merangkai peristiwa-peristiwa di dalam cerita dengan memanfaatkan segenap potensi bahasa yang ada. Kepiawaiannya dalam memanfaatkan potensi bahasa dapat dilihat pada tulisan Panuti Sudjiman berjudul "Beberapa Pilihan Leksikal dalam Cerita Pendek 'Jakarta' dan Efek yang Ditimbulkannya" (1993: 22-33) dalam buku Bunga Rampai Stilistika (1993). Sayangnya, pembicaraan tentang karya-karya Totilawati Tjitrawasita lebih banyak pada cerpen yang berjudul "Jakarta". Hal itu kemungkinan besar dikarenakan cerpen itu yang telah lebih dahulu dibicarakan oleh HB. Jassin yang dikenal sebagai kritikus andal, bahkan dijuluki Paus Sastra Indonesia sehingga kritikus lain berbaris di belakangnya. Padahal, cerpen Totilawati Tjitrawasita yang lain tidak kalah kualitasnya, khususnya cerpen "Surabaya".

Sangatlah tepat jika pada akhirnya Seno G umira Ajidarma dan penerbit Kompas memilih cerpen "Surabaya" menjadi salah satu cerpen terbaik yang diterbitkan dalam antologi Cerpen Kom pas Pilihan 1970 - 1980: Dua Kdamin bag Midin (2003). D alam cerpen "Surabaya", Totilawati Tjitrawasita banyak sekali menggunakan bahasa kiasan untuk "menghidupkan" suasana sebuah tempat, baik desa maupun kota sebagai setting cerita sehingga tempat tersebut tidak semata-mata menjadi "tempat" terjadinya sebuah peristiwa, tetapi juga mewakili gambaran perasaan manusia yang hidup di dalamnya. Aspek nonhuman digambarkan sebagai human.

Berdasarkan latar belakang tersebut, masalah yang menjadi fokus penelitian ini adalah bagaimanakah penggunaan bahasa kiasan dalam cerpen "Surabaya" dan efek yang ditimbulkannya? Tujuannya adalah untuk mengungkap dan mendeskripsikan penggunaan bahasa kiasan dan efeknya dalam cerpen "Surabaya" agar dapat meluaskan penelitian terhadap karya-karya pengarang perempuan Jawa Timur umumnya dan khususnya karya-karya Totilawati Tjitrawasita. Untuk membahas masalah dan mencapai tujuan tersebut, penulis menggunakan pendekatan stilistika. Kiasan merupakan salah satu jenis gaya bahasa atau style (Keraf, 1985: Sudjiman, 1995:7). Oleh karena itu, untuk mengungkap dan mendeskripsikan penggunaan kiasan di dalam cerpen "Surabaya", penulis menggunakan pendekatan stilistika.

Sarana utama penulisan karya sastra adalah bahasa, ia seperti kanvas dan cat bagi seorang pelukis. Indah atau tidaknya sebuah lukisan tergantung pada kemampuan pelukis memilih dan memadukan warna serta bagaimana menggoreskannya ke dalam kanvas. Indah atau tidaknya sebuah karya sastra tergantung pada kemampuan pengarang memilih dan menggunakan bahasanya. Karya sastra, sebagaimana lukisan bagi pelukis, adalah alat komunikasi seorang pengarang kepada para pembacanya. Keberhasilan komunikasi itu sangat ditentukan oleh kemampuan pengarang memanfaatkan segala potensi dan kemungkinan yang ada dalam bahasa (Sudjiman 1993: 6-7). Karya fiksi merupakan sebuah dunia dalam kemungkinan karena dunia yang berisi gagasan, perasaan, dan angan-angan pengarangnya itu di- 
bangun dengan sarana bahasa. Bahasa dapat dimanfaatkan untuk menciptakan sebuah realitas atau dunia baru yang tidak hanya dapat berupa rekonstruksi dari realitas yang sudah ada sebelumnya, tetapi juga sebuah realitas yang "mungkin" ada. Gambaran dunia yang dibangun oleh pengarang akan tercipta dalam pikiran dengan sarana bahasa sebagai jembatannya. Oleh karena itu, bahasa menjadi salah satu faktor yang sangat penting bagi seorang pengarang (Nurgiyantoro 1995:272).

Studi yang berusaha mengungkap penggunaan bahasa atau gaya bahasa seorang pengarang dikenal dengan nama stilistika. $\mathrm{G}$ aya yang dimaksud mengacu pada bagaimana seorang pengarang melakukan pilihan bahasa untuk mengungkapkan pikirannya dalam karya sastra (Aminuddin, 1995: v). Stilistika merupakan bagian ilmu bahasa yang mengkaji secara khusus penggunaan bahasa dalam karya sastra. Bahasa dalam karya sastra memerlukan pengkajian khusus karena bahasa dalam karya sastra berbeda dengan bahasa yang digunakan dalam komunikasi sehari-hari, yang digunakan secara spontan dan aktivitas bahasanya terasa sebagai "bahasa normal” (Turner, 1973:7- 8). Salah satu pendekatan yang penting dalam studi stilistika didasarkan pada analisis makna ke dalam elemen makna denotatif dan makna konotatif. Hal itu dalam stilistika disebut juga elemen makna pikiran dan sebuah ekspresi atau afektif. Analisis secara objektif ini analisis refleks sebuah konsep tertua dari bahasa dan sastra (Turner, 1973:27).

Ada dua pandangan dalam menyikapi pengkajian bahasa di dalam teks sastra, yaitu pandangan yang melihat bahasa dalam teks sastra sebagai kode estetik dan pandangan yang melihat bahasa dalam teks sastra sebagaimana bahasa yang menjadi objek kajian linguistik (Aminuddin,1995). D alam penelitian ini, bahasa dalam teks sastra dipandang sebagai kode estetik.

\section{METODE}

Penelitian ini menggunakan metode kualitatif deskriptif, yaitu bertujuan membuat deskripsi mengenai fakta-fakta, sifat-sifat, dan hubunganhubungan antarfenomena yang diteliti (Nazir, 1999:63). D ata yang digunakan merupakan data kualitatif, yaitu bersifat ideografis berupa paparanpaparan kebahasaan (Bogdan dan Taylor dlm. Moloeng, 2002:3).

Sumber data penelitian ini adalah cerpen berjudul "Surabaya" karya Totilawati Tjitrawasita yang terbit dalam buku Cerpen Kampas Pilihan 1970-1980: Dua Keamin bag Midin (ed. Seno Gumira Ajidarma). Buku tersebut diterbitkan oleh penerbit Kompas, Jakarta, pada tahun 2003. Pengumpulan data dilakukan dengan teknik baca dan catat. Peneliti membaca cerpen "Surabaya" karya Totilawati Tjitrawasita secara berulangulang dan mencatat pada kartu data kutipan-kutipan yang menunjukkan fenomena pemakaian bahasa kiasan sebagai data. Pengumpulan data dengan teknik baca juga digunakan untuk menjaring data dari sumber sekunder terkait dengan informasi tambahan mengenai Totilawati Tjitrawasita dan karya-karyanya serta pembicaraan para tokoh sebelumnya. Setelah data terkumpul, selanjutnya peneliti memilah dan memilih data-data tersebut berdasarkan kesamaan informasi untuk dikelompokkan berdasarkan jenis bahasa kiasan yang digunakan. Setelah tabulasi data selesai, berikutnya dilakukan analisis dan interpretasi terhadap data tersebut dengan menggunakan teknik analisis bolak balik dari teks ke konteks dan sebaliknya.

\section{HASIL DAN PEMBAHASAN}

Penelitian ini menghasilkan temuan bahwa ada tiga bahasa kiasan yang paling banyak digunakan oleh Totilawati Tjitrawasita dalam cerpen "Surabaya", yaitu simile metafora, dan personifikasi. Ketiga bahasa kiasan itu, mendominasi 
pilihan bahasa yang digunakan Totilawati Tjitrawasita. Hal itu berefek pada gambaran tentang "merananya" sebuah dusun di pegunungan kapur dan "kejamnya" Kota Surabaya.

\section{Penggunaan Personifikasi, Simile, Meta- fora, dan Efeknya}

Personifikasi, simile, dan metafora seringkali digunakan secara bersama dalam satu narasi. O leh karena itu, kesan bayangan angan tentang objek atau hal yang digambarkan menjadi semakin kuat dan jelas. Personifikasi atau penginsanan adalah kiasan yang menggambarkan benda-benda mati atau benda-benda yang tidak bernyawa seakanakan mempunyai sifat-sifat kemanusiaan. Bendabenda mati yang diperbandingkan bertindak dan berbuat seperti manusia, misalnya dalam tindak tanduk, perasaan, dan perwatakannya (Keraf, 1985:141-142). Simile atau persamaan adalah perbandingan yang bersifat eksplisit, yaitu secara langsung menyatakan sesuatu hal sama dengan hal lainnya dengan menggunakan kata-kata pembanding: sepeti, sama, sebacai, bagaikan, laksama, dan sebagainya (Keraf, 1985:138). Metafora membandingkan dua hal secara langsung, tanpa menggunakan kata-kata pembanding: seperti, bak, bagaikan, bagai, dan sebagainya. Bentuknya mirip dengan simile, hanya saja smiletidak secara langsung karena menggunakan kata-kata pembanding. Karena tidak menggunakan kata-kata pembanding, metafora juga lebih singkat bentuknya. Pokok pertama langsung dihubungkan dengan pokok kedua serta dapat menduduki fungsi apa saja sehingga dapat berdiri sendiri sebagai kata, tidak tergantung pada konteks. A kan tetapi, similesangat bergantung pada konteks untuk memahami maknanya (Keraf, 1985:139).

Cerpen "Surabaya" dibuka dengan gabungan bahasa kiasan simile, metafora, dan personifikasi sebagaimana tampak pada kutipan data berikut ini: "Setiap subuh, bedug dipukul bertalu-talu, dan bunyi azan yang mirip rintihan itu menyobek udara gersang pedusunan miskin di bukit kapur." (Tjitrawasita, 2003:249). Pilihan bahasa kiasan simile "bunyi azan yang mirip rintihan" dan metafora "menyobek udara", serta personifikasi "bunyi azan yang mirip rintihan itu menyobek udara gersang..." itu mampu membangkitkan bayangan angan akan penderitaan penduduk di sebuah pedusunan kapur yang diceritakan dalam cerpen "Surabaya". Bunyi azan mirip rintihan dikarenakan pengeras suaranya tidak berfungsi dengan baik atau yang mengumandangkan azan adalah orang yang sudah sangat tua sehingga suaranya tidak lantang lagi. "Menyobek udara" merupakan sebuah metafora karena kata kerja/ tindakan "menyobek" disandingkan dengan udara, suatu yang tidak dapat disobek. Hal itu menggambarkan "rusaknya" suasana subuh/ pagi karena bunyi azan yang mirip rintihan. D alam konteks yang lebih panjang: "bunyi azan yang mirip rintihan itu menyobek udara gersang pedusunan miskin di bukit kapur" menunjukkan suatu penginsanan karena tindakan "menyobek" lazimnya dilakukan oleh manusia, bukan oleh bunyi. Dengan pilihan bahasa yang demikian untuk mengawali cerpen "Surabaya", Totilawati Tjitrawasita sudah membangun suasana "muram" dan tidak menyenangkan. Narasi-narasi cerpen itu selanjutnya dipenuhi pilihan bahasa kiasan yang berefek "muram", "suram", "sedih", "ngeri", dan "merana" untuk mendukung dan menghidupkan suasana kemiskinan dan kekalahan manusia oleh alam atau kekuatan yang lebih besar di luar dirinya.

Sebagaimana fungsi bahasa kiasan, yaitu untuk mendapatkan gambaran angan yang jelas dengan cara menyatakan suatu hal dengan hal yang lain, personifikasi, simile, dan metafora dalam cerpen "Surabaya" juga menunjukkan fungsi yang sama. Gaya bahasa personifikasi narasi cerpen ini meneguhkan bagaimana pengarang menyejajarkan aspek nonhuman dan human 
Tonggak-tonggak jati mencuat tajam meraih langit, nampak seperti serdadu-serdadu yang siap menusuk punggung penduduk di dusun itu. Mereka pun lantas bergumam panjang pendek, memandang masam pada tonggak-tonggak yang bisu. G ambaran kengerian terbayang di wajah mereka yang pucat lesu, seolah tonggak itu menjelma kembali menjadi pedang-pedang tajam, yang menyembelih habis orang-orang muda di dusun itu, hampir lima belas tahun yang silam, tatkala dusun itu dibakar habis oleh api kecurigaan zaman PKI.

(Tjitrawasita, 2003:249-250)

D alam kutipan data tersebut terlihat bahwa alam direpresentasikan sebagai human melalui penggunaan bahasa kiasan metafora, personifikasi, dan smile "Tonggak-tonggak jati mencuat tajam meraih langit, nampak seperti serdaduserdadu yang siap menusuk punggung penduduk dusun itu", "tonggak-tonggak membisu", dan "seolah tonggak itu menjelma kembali menjadi pedang-pedang tajam yang menyembelih habis orang-orang muda di dusun itu". Ada tiga kata penginsanan yang dilekatkan pada subjek nonhuman "tonggak-tonggak jati", yaitu "meraih", "bisu", dan "menyembelih". A da metafora "meraih langit" yang menggambarkan runcingnya tonggak-tonggak jati untuk membangun kesan mengerikan dan "api kecurigaan" zaman PKI yang juga menggambarkan suasana kengerian zaman itu yang diwarnai rasa saling curiga. Kondisi alam dusun Kalidami tempat Mbok Soma tinggal digambarkan sangat menakutkan dan mengerikan dengan cara "dihidupkannya" dan "dibandingkannya" benda-benda mati berupa tonggak-tonggak jati dengan manusia yang mengingatkannya pada peristiwa politik berdarah yang telah "melenyapkan" rasa kemanusiaan manusia kala itu. Petikan data itu juga menegaskan kondisi dusun yang lebih banyak dihuni oleh manusia lanjut usia karena kaum mudanya justru telah menjadi korban pembantaian PKI. Oleh karena itu, "bunyi azan yang mirip rintihan" keluar dari mulut orang yang sudah tua.

Gambaran kekeringan dan kegersangan lingkungan alam fisik D usun Kalidami itu selanjutnya berulang-ulang dikemukakan dalam narasi dengan personifikasi dan metafora, seperti berikut: "di sana, masih tertinggal di gundukan bukit kapur yang gersang, di antara cuatan tonggak jati yang merana", "gambaran wajah kita sekeluarga, yang dipahat dan diukir matahari bukit kapur yang gersang, di antara cuatan tonggak jati yang menusuk langit di tanah kelahiran kau" untuk memberikan kesan yang kuat terhadap faktor alam yang secara alamiah tidak mendukung kehidupan dan memaksa penghuninya untuk meninggalkan dusun itu.

Gambaran sendu masa silamnya, nampak terpahat pada wajah oroknya yang pulas di pembaringan. Ia pun terpanggil untuk mengabarkan kecerahan hidupnya pada emboknya, di sana, masih tertinggal di gundukan bukit kapur yang gersang, di antara cuatan tonggak jati yang merana.

$$
\text { (Tjitrawasita, 2003:250) }
$$

...Betapapun, ia tetap merupakan gambaran wajah kita sekeluarga, yang dipahat dan diukir matahari bukit kapur yang gersang, di antara cuatan tonggak jati yang menusuk langit di tanah kelahiran kau.

(Tjitrawasita, 2003:250)

Mbok Soma terpaksa meninggalkan dusunnya di Pegunungan Kapur untuk menyusul Juminten, anaknya, yang telah lebih dahulu merantau ke Surabaya karena tidak tahan dengan kemiskinan dan kengerian dusunnya. Sekali lagi, keterangan bahwa anak Mbok Soma yang bernama Juminten telah meninggalkan D usun Kalidami menjelaskan bahwa yang tertinggal di dusun itu memang hanya orang-orang tua dengan kondisi alam yang gersang 
("cuatan tonggak jati yang merana", kiasan yang menggambarkan kondisi alam yang gersang) dan suasana mengerikan ("cuatan tonggak jati yang menusuk langit", kiasan yang menggambarkan tajam/ runcingnya tonggak-tonggak jati itu). Mbok Soma tidak pernah tahu bagaimana nasib Juminten di Surabaya, tetapi ia semakin yakin untuk hijrah ke Surabaya setelah mendapat surat dari Juminten yang mengabarkan kelahiran anaknya. Juminten tidak pernah memberi tahu Mboknya di dusun tentang kondisi kehidupannya di Surabaya. Metafora "kecerahan hidupnya" menggambarkan lahirnya anak Juminten, bukan kehidupan sehari-harinya.

G ambaran kemiskinan dan kekalahan manusia (Mbok Soma) oleh kekuatan yang lebih besar di luar dirinya tidak hanya terlihat di dusunnya, tetapi juga sepanjang perjalanannya untuk hijrah ke Kota Surabaya. Kereta api barang yang ditumpanginya berjalan terseok-seok di pegunungan kapur dan setiap saat harus mengalah pada kereta api dari kelas yang lebih baik. Beratnya perjalanan untuk hijrah ke Surabaya "dihidupkan" dengan pilihan bahasa kiasan personifikasi kereta tua yang digambarkan sebagai human "yang menjerit-jerit" dan "terbatuk-batuk" karena berat memikul beban "di atas punggungnya".

Kereta barang yang ditumpanginya, bergerak lambat di atas rel yang melilit sepanjang pantai utara Laut Jawa. Peluitnya menjeritjerit seperti ringkik kuda. Lantas loko yang tua itu terbatuk-batuk mengepulkan asap ke udara. D engan berat, kereta itu menjalankan tugasnya, menarik beban yang terpikul di atas punggungnya, berderak-derak memecah tamasya bisu di gunung kapur. Sebentar-sebentar lok tua itu berhenti, mengambil dan menurunkan muatan. (Tjitrawasita, 2003:251-252)

D usun Kalidami yang disejajarkan dengan human melalui pemakaian personifikasi dalam narasinya menunjukan "watak" nya yang kejam dan tidak bersahabat dengan para penghuninya, memaksa Mbok Soma hijrah ke Surabaya sebagai kota harapan. A kan tetapi, Surabaya tidak seramah dan sebaik yang diharapkannya, kota itu bahkan lebih kejam dari dusunnya yang miskin dan merana. G ambaran "kekalahan" Mbok Soma sudah tampak dalam perjalanan kereta yang membawanya, yaitu kereta api barang dengan lokomotif tua yangjalannya sudah terseok-seok terkalahkan oleh kereta api cepat: "Hatinya pun ikut bergoyanggoyang, teriris oleh hukum alam yang disaksikannya, dalam secuil kejadian yang tergambar di depan matanya." Baru dalam perjalanan kereta api ke Surabaya, Mbok Soma sudah merasakan jurang perbedaan yang akan ditemuinya. Perasaan Mbok Soma itu digambarkan dengan pilihan bahasa kiasan metafora berikut: "Aneh, tonggak jati yang selama ini dirasa menusuk-nusuk perasaanma, nampak lebih dekat ke dalam hatinya." Kekejaman kota besar bernama Surabaya itu sudah dirasakan Mbo Soma saat masih dalam perjalanan.

Surabaya yang dibayangkan sebagai kota harapan yang akan memberinya kehidupan lebih baik, ternyata lebih kejam dari dusunnya di pegunungan kapur. Pilihan bahasa kiasan personifikasi dan metafora mendominasi narasi penggambaran Kota Surabaya sehingga kesan "kejam" sangat tampak. Berikut petikan datanya.

Surabaya yang cerah ceria, acuh tak acuh saja menyambut kedatangan tamunya. Waktu kereta berhenti di Stasiun Pasar Turi, ia tak sadar bahwa telah sampai di akhir perjalanannya. Lautan manusia yang lalu lalang di perut stasiun, tak satu pun yang dikenalnya, dan tak satu pun yang memperhatikannya.

(Tjitrawasita, 2003:252)

Mbok Soma menjadi pusing oleh jawaban yang berbeda-beda, ia pun semakin larut tersesat di rimba raya ketakacuhan Kota Surabaya.

(Tjitrawasita, 2003:252) 
D an, Surabaya tetap berdiri dengan pongahnya, tak peduli oleh tangis perempuan tua yang membasahi buminya. Lalu lintas yang sibuk, tak satu pun yang mau menoleh padanya, dan gedung-gedung megah yang memagarinya, membisu saja pada kenyataan yang terjadi di depan matanya.

\section{(Tjitrawasita, 2003:253)}

Surabaya, kota yang mirip mulut raksasa, menyedot ribuan urbanisasi ke dalam perutnya, dan memuntahkannya kembali ke kaki lima, emperan cina, kolong jembatan, dan gotgot mesum yang merajah tubuh kota. Mbok Soma dituntun tangan sang nasib ke tepi jurang tak berdasar yang menganga di depannya.

(Tjitrawasita, 2003:253)

Kota Surabaya digambarkan berwatak kejam dengan pilihan bahasa kiasan personifikasi ("Surabaya yang cerah ceria, acuh tak acuh saja menyambut kedatangan tamunya", "ketakacuhan Kota Surabaya", "Surabaya yang pongah dan tak peduli", "lalu lintas yang sibuk dan tak mau menoleh", "gedung-gedung megah membisu", "menyedot ribuan urbanisasi ke dalam perutnya, dan memuntahkannya kembali"), metafora ("perut stasiun", "lautan manusia", "larut tersesat", "rimba raya", "tangan sang nasib"), dan simile ("Surabaya, kota yang mirip mulut raksasa"). Pilihan-pilihan bahasa itu mampu membangun gambaran angan tentang Kota Surabaya yang kejam, yang tidak ramah kepada para pendatang. A palagi para pendatang yang tidak bermodal, seperti Mbok Soma, Juminten, dan Samino.

Juminten yang lebih dahulu datang ke Surabaya tidak memiliki pendidikan dan keterampilan yang cukup, apalagi modal uang sehingga seperti pendatang lainnya, menjadi bagian dari kaum marginal yang bekerja di sektor-sektor informal tanpa kepastian pendapatan, apalagi kepastian masa depan. Mereka terpaksa bekerja sebagai buruh harian, tukang becak, pengais sampah atau pemulung dan karena tidak mampu membeli rumah mereka pun mendirikan gubuk-gubuk liar dan kumuh di sudut-sudut kota.

D engan menggunakan bahasa kiasan yang dipilih dengan baik, Totilawati Tjitrawasita dapat menggambarkan dan menyampaikan pesan bahwa "alam itu" bukan benda mati yang dapat ditundukkan dengan mudah oleh manusia. Manusia merupakan bagian yang kecil saja dari alam dan bukan tidak mungkin manusia juga dapat dikalahkan oleh alam. Alam atau kekuatan di luar manusia menggambarkan makrokosmos dan manusia sebagai perwujudan mikrokosmos merupakan bagian kecil saja di dalam makrokosmos. Sebagaimana Juminten dan Samino yang terpaksa meninggalkan kampungnya untuk memperbaiki nasib di Surabaya, Mbok Soma juga dipenuhi harapan yang sama. A kan tetapi, ketiganya mengalami nasib yang sama dikalahkan oleh alam, menjadi kaum urban yang tragis. Kehidupan Juminten dan Samino di Surabaya tidak lebih baik dari Mbok Soma di D usun Kalidami. Potret kriminalitas dan kemiskinan menyelimuti keluarga Juminten: “..Mbok Soma menebarkan pandangannya menelusuri gubug anaknya, bolong-bolong pada gedegnya, tak tegak lagi berdirinya, sinar matahari menusuk lantai, menerobos masuk lewat genteng yang pecah-pecah sebesar kepala." (Tjitrawasita, 2003: 254). Pilihan bahasa kiasan yang digunakan dalam kutipan tersebut dapat membawa pembaca pada gambaran manusia yang terkalahkan dan terpinggirkan oleh alam.

Sebagai manusia Jawa, Mbok Soma menggunakan dasar falsafah Jawanya untuk mengatasi kebimbangan antara pilihan dusunnya yang miskin dan merana atau Kota Surabaya yang megah tapi kejam. Pilihan Mbok Soma tetap bertahan di Surabaya karena di sanalah ia dapat berkumpul dengan anak, menantu, dan cucunya. Totilawati Tjitrawasita menggambarkan ketetapan hidup 
Mbok Soma dengan pilihan bahasa kiasan personifikasi berikut. "Biarlah gunung kapur meneruskan sejarahnya tanpa aku. Di sini kita mulai babak yang baru, di antara kamu, suamimu, dan orok yang kecil ini." (Tjitrawasita, 2003:255).

\section{SIMPULAN}

Salah satu keberhasilan seorang pengarang agar dapat menyampaikan dan mengkomunikasikan gagasan, pikiran, dan perasaannya kepada pembaca melalui karya sastra adalah pada ketepatannya dalam memilih dan menggunakan bahasa. A palagi jika gagasan, pikiran, dan perasaannya itu dituangkan dalam cerita pendek yang memerlukan kepadatan bahasa. Pilihan menggunakan bahasa kiasan yang tepat, seperti personifikasi, metafora, dan simile sebagaimana tampak dalam cerpen "Surabaya" akan membuat gagasan, pikiran, dan perasaan dapat disampaikan dengan efektif. Melalui pemilihan dan pemakaian bahasa kiasan yang tepat, Totilawati Tjitrawasita berhasil membangun suasana dalam cerpennya yang dapat mendukung gagasan, pikiran, dan perasaan tentang perjuangan hidup manusia di tengah alam, baik desa maupun kota, yang tidak berpihak kepadanya.

\section{DAFTAR PUSTAKA}

A minuddin. (1995). Stilistika: Pengantar Memahami Bahasa dalam Karya Sastra Semarang: IKIP Semarang Press.

Hutomo, S. S.(1995). Wajah Sastra Indonesia di

Surabaya. Surabaya: Pusat D okumentasi Suripan Sadi Hutomo.
Hoerip, S. (1979). Ceita Pendk Indonesia 4 Jakarta: Pusat Pembinaan dan Pengembangan Bahasa.

Keraf, G. (1985). Diksi dan Goja Bahasa. Jakarta: G ramedia. K ridalaksana, Harimurti. 1982. Kams Istilah Linguistik. Jakarta: G ramedia. Moleong, L.J. (2002). Metoddog PenditianKualitatif Cet. XVII. Bandung: PT Remaja Rosdakarya. Nazir, M.(1999). MetodePenditian Jakarta: G halia Indonesia.

Nurgiyantoro, B. (1995). Tear Pengkajian Fiksi. Yogyakarta: Gadjah Mada University Press.

Pradopo, R. D. (1995). Beberapa Teeri Sastra, Metode Knitik, dan Penerapannya. Yogyakarta: Pustaka Pelajar.

Sudjiman, P. (1983). Kams Istilah Sastra. Jakarta: Gramedia. . (1995). Bunga Rampai Stilistika Jakarta: Grafiti Press.

Sungkowati, Y. (2013). "Perempuan-Perempuan Pengarang Jawa Timur": Kajian Feminis. Atavisme, 16 (1), 57-69.

Tim Penyusunan Kamus. (1994). Kamus Besar Bahasa Indonesia. Edisi Ke-2. Jakarta: Balai Pustaka.

Tjitrawasita, T. (2003). "Surabaya”. D alam Cerpen Kompas Pilihan 1970 - 1980: Dua Kdamin Bağ Midin (ed. Seno Gumiro Ajidarma). Jakarta: Kompas.

Turner, G.W.(1997). Styistics Middlesex: Pengguin Book. 